
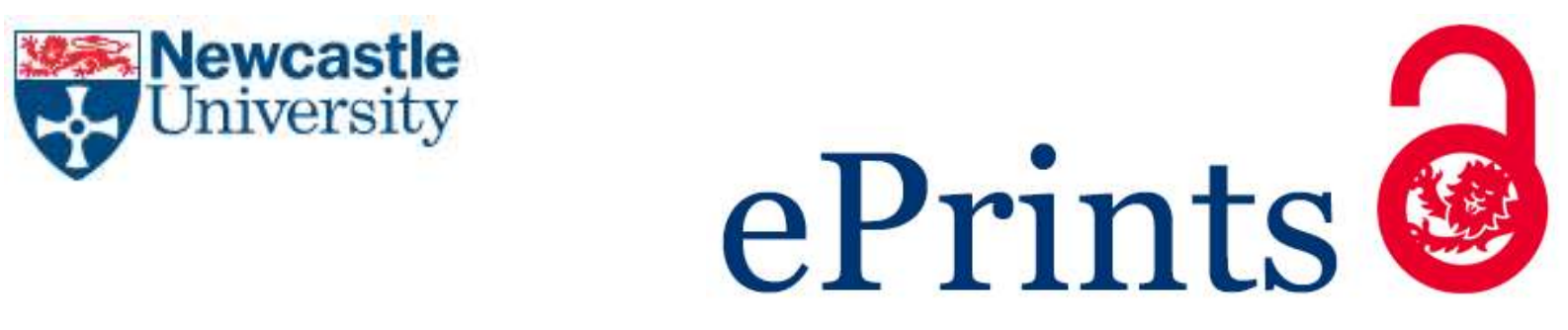

Al-Shaer H, Zaman M. Board gender diversity and sustainability reporting quality. Journal of Contemporary Accounting \& Economics 2016

\title{
Copyright:
}

(C) 2016. This manuscript version is made available under the CC-BY-NC-ND 4.0 license

DOI link to article:

http://dx.doi.org/10.1016/j.jcae.2016.09.001

Date deposited:

$19 / 10 / 2016$

Embargo release date:

28 March 2018

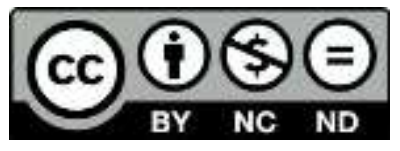

This work is licensed under a

Creative Commons Attribution-NonCommercial-NoDerivatives 4.0 International licence 


\title{
BOARD GENDER DIVERSITY AND SUSTAINABILITY REPORTING QUALITY
}

\begin{abstract}
Based on the notion that a diverse board will take a more balanced view and pay greater attention to social responsibility and stakeholder concerns, this paper examines the effect of board gender diversity, measured using a range of proxies, on sustainability reporting quality. After controlling for corporate governance as well as firm reporting incentives, reporting behaviour and reporting environment, we find that gender diverse boards are associated with higher quality sustainability reports and independent female directors have greater effect on sustainability reporting quality than female directors. Our findings have implications for policy formulation and provide evidence for a softer 'comply or explain' (as opposed to quota based) approach to encourage board gender diversity and its effects on sustainability reporting quality.
\end{abstract}

Key words: boards, diversity, gender, sustainability reporting.

JEL Code(s): M14, M41, M42 


\section{BOARD GENDER DIVERSITY AND SUSTAINABILITY REPORTING QUALITY}

\section{INTRODUCTION}

This paper examines the effect of board gender diversity on sustainability reporting quality. We use five alternative proxies for gender diversity and measure sustainability reporting quality using an index. Our study is based on the UK context which is characterised by a softer comply or explain approach (as opposed to a mandatory one), affecting change in boardrooms and corporate accountability. We provide evidence of gender diverse boards, in particular independent female directors, having a significant positive association with sustainability reporting quality after controlling for corporate governance characteristics and firm reporting incentives, reporting behaviour and reporting environment.

Corporate governance reforms emphasise diversity in boardrooms (Higgs Report, 2003; Davies Report, 2011; 2015; European Commission, 2014). Many companies are now increasingly issuing sustainability reports (Simnett, 2012; Mock et al., 2013)1. In the UK, the Higgs Report (2003) and the Davies Report (2011) recommended diversifying boards with people from a range of perspectives and backgrounds. Similarly, the European Commission (2012; 2014) has set targets for women on boards and its report on women in decision-making notes that the quality of ethical behaviour in companies is affected by the proportion of females on the board. This paper investigates the relationship between board gender diversity and sustainability reporting quality.

\footnotetext{
1 Sustainability reports include quantitative and qualitative information on financial/economic, social/ethical and environmental performance and seek to reflect a company's economic, social and environmental behaviour (KPMG, 2011; GRI, 2013). Sustainability reports are a structured way an entity documents its economic, environmental and social performance that gives companies a means to report on how non-financial factors interact with financial ones and ultimately drive a company's value (Mock et al., 2007; 2013).
} 
Our examination of the effects of board gender diversity on sustainability reporting quality differs from and extends prior research in a number of ways. First, countries differ in their approach to promoting board gender diversity. Unlike the mandatory quota approach adopted, for example, in Norway and Spain, the UK has a voluntary approach to promoting good corporate governance practice. The Higgs Report (2003) on the role of non-executive directors argued that diversity on boards can enhance their effectiveness. Subsequently, the Davies Report (2011) recommended that listed companies should establish policy concerning boardroom diversity and set measurable objectives for its implementation. The latest Davies Report (2015) reviewing board gender diversity observes that the UK voluntary approach is working. Unlike prior research on gender effects in accounting which are predominantly based on data from the US (see Srinidhi et al., 2011; Gul et al., 2011; Gul et al., 2013), or Australia (see Hodge et al., 2009; Chapple and Humphrey 2014; Capezio and Mavisakalyan, 2015) or cross-country (see Mock et al., 2007; Ruhnke and Gabriel, 2013; Junior et al., 2014), our study is based on the UK context where there is a paucity of research on gender effects on sustainability reporting quality. To the best of our knowledge, our paper is the first to provide recent evidence on the effect of board gender diversity, in particular of independent female directors, on sustainability reporting quality.

Second, in focusing on the effect of board gender diversity on sustainability reporting quality, we examine a range of measures of gender diversity: number of female directors on the board, the proportion of female directors on the board, number of independent female directors on the board and the Shannon and Blau indices of diversity. This contrasts, for example, with Liao et al. (2015) whose focus is on the effect of percentage of female directors on whether a firm discloses participation in the carbon emission project.

Third, our focus is not on a particular disclosure, for example whether a company discloses participation in a carbon emission project measured using a dummy (cf Liao et al., 
2015), but rather on sustainability reporting quality which we measure using an index. ${ }^{2} \mathrm{We}$ thus go beyond mere sustainability disclosure. Our focus contrasts, for example, with the cross-country study of Simnett et al. (2009) which does not investigate the effect of corporate governance on sustainability reporting quality. The typology applied in our paper helps in assessing sustainability reporting quality by applying thresholds compared to the dichotomous measure used by Liao et al. (2015) or the two step approach used in Simnett et al. (2009). ${ }^{3}$ We also undertake additional analysis and examine specifically the effect of board gender diversity on whether a company has a separate sustainability committee and whether its sustainability report is externally assured.

Fourth, we recognise that sustainability reporting quality could be affected by some underlying firm characteristics. Thus in examining the effect of board gender diversity on sustainability reporting quality we control for the effect of firm reporting incentives, reporting environment and reporting behaviour. ${ }^{4}$ We provide evidence that after controlling for these firm related characteristics, board gender diversity has a positive significant association with sustainability reporting quality.

Our paper is related to but also markedly different from Liao et al. (2015): (i) their focus is on examining whether a firm discloses its participation in the carbon disclosure project whereas we focus on sustainability reporting quality; (ii) their study relies on diversity measured using the percentage of female directors whereas we use a number of proxies of gender diversity including independent female directors; (iii) their study does not take into

\footnotetext{
2 This is on a scale of $0-4$, whereby we score a firm 0 if it does not publish a sustainability report; $1=$ if sustainability report exists; $2=$ if sustainability report exists and the company has a sustainability committee affiliated with the board of directors; $3=$ if sustainability report exists and the report is assured by an external assurer provided by a non-audit firm; score $4=$ if sustainability report exists and is externally assured by one of the Big 4 or other audit firm.

${ }^{3}$ Simnett et al. (2013) used a dummy variable taking the value of 1 if sustainability reports are assured and 0 otherwise in the first step, whereas in the second step, it tests whether the assurance provider belongs to the audit profession.

${ }^{4}$ We follow Daske et al. (2013) and use factor analysis technique in controlling for these firm specific characteristics.
} 
consideration firm specific characteristics that might influence the disclosure of participation in the carbon disclosure project whereas we provide evidence that after controlling for firm reporting incentives, reporting behaviour and reporting environment, gender diverse boards have a positive significant effect on sustainability reporting quality.

Overall, controlling for corporate governance characteristics, reporting incentives, reporting behaviour, and reporting environment, we find that gender diverse boards are associated with higher quality sustainability reports and independent female directors have greater effect on sustainability reporting quality than female directors. Moreover, proxies that capture incentives for more transparent reporting also have a significant and positive association with sustainability reporting quality. Our results are supported by detailed testing of model specification and sensitivity analysis, including tests dealing with size effects and correlated variables issues. Our analysis is based on a sample of companies listed in 2012 in the UK FTSE350, operating under a softer comply or explain approach to governance and board diversity (Adams, 2015), and provides recent evidence on the effect of board gender diversity on sustainability reporting quality.

The remainder of the paper is presented in four further sections. The next section reviews the literature in order to develop hypotheses. The third section sets out the research study in terms of sample, data and model. A fourth section reports the empirical results. The final section provides a summary and draws conclusions.

\section{BACKGROUND AND HYPOTHESES DEVELOPMENT}

In this section of the paper we explore prior research related to board gender diversity and sustainability reporting to develop our hypotheses. We do not aim to review the whole literature, but rather focus on papers pertinent to establishing the potential effect of gender diversity on sustainability reporting quality. We first cover sustainability reporting and then gender diversity effects. 


\section{Sustainability Reporting Quality}

Sustainability reports include quantitative and qualitative information on financial/economic, social/ethical and environmental performance and seek to reflect a company's economic, social and environmental behaviour (GRI, 2013). The existence of sustainability reports does not mean an increase in the quality of the reported information (Junior et al., 2014). Simnett et al. (2009) find that assurance of sustainability reports enhances the credibility and reliability of reports and helps to build corporate reputation. Concerns about the integrity of information disclosed in reports lead to demands for more transparent reports. Firms respond to these demands by providing external independent assurance on sustainability reports. Previous studies suggest assurance of sustainability reports enhances their quality, and that the quality of these reports will be greater when assurance is provided by an auditing profession (see for example Hodge et al., 2009; Manetti and Becatti, 2009; Simnett et al., 2009; GRI, 2013;). Junior et al. (2014) provide a historical analysis of sustainability reporting and assurance of sustainability reports. They argue that sustainability reports help enhance dialogue among stakeholders and hence improve the decision-making process.

\section{Board Diversity Matters}

Our expectations of the effect of gender diversity on sustainability reporting quality is based on a review of the literature which provides a number of interrelated reasons. First, diversity on boards may affect decision making due to more varied perspectives and non-traditional approaches to problems (Adams et al., 2015). A diverse board might signal its understanding of the business environment (Miller and Triana, 2009; Triana et al., 2013) and may increase the ability of boards to recognize the interests of a variety of stakeholder groups (Harjoto et al., 2014). It may also help companies benefit from expertise of individuals who can provide a 
variety of resources including prestige, legitimacy, financing, knowledge and diversity (Terjesen et al., 2009).

Second, female directors are not mere tokens but are different from their male counterparts and have different priorities (Adams and Ferreira, 2009; Adams and Funk, 2012). Female directors differ in leadership styles (Bear et al., 2010) and are more likely to support community group and social responsibility projects (Hillman et al., 2002). The presence of female directors on boards can reinforce mechanisms of stakeholder engagement and increase the credibility of corporate reports (Manetti and Toccafondi, 2012). Also, female directors differ from male directors in terms of personality, communication style, educational background and career experience (Liao, et al., 2015). Female directors are more averse to litigation and reputation loss (Srinidhi et al., 2011). Due to these differences a gender diverse board may affect sustainability reporting quality.

Third, female directors are more likely to be stakeholder oriented, concerned about ethical practices and socially responsible behaviour and also be inclined to take actions to reduce perceived risks (Carter et al., 2003; Adams and Ferreira, 2009). Adams (2015) reports that there are differences in ethical behaviour between women and men, and female directors have different values and are more stakeholder oriented than male directors. Females tend to adopt a more trust-building relationship compared to males and thus may put more emphasis on greater engagement with stakeholders and in reducing information asymmetry (Gul et al., 2013). In addition they are more sensitive to social and ethical issues (Bear et al., 2010; Hafsi and Turgut, 2013; Isidro and Sobral, 2014). It is thus likely that due to females' higher concerns for social responsibility issues and greater stakeholder orientation a gender diverse board may affect sustainability reporting quality.

Our expectations of a gender diverse board affecting sustainability reporting quality is further supported by empirical research. The relationship between gender and firm performance continues to be the subject of much research but findings are often mixed 
(Hillman and Dalziel, 2003; Adams and Ferreira, 2009). ${ }^{5}$ However, research examining the impact of gender diversity on firm level financial outcomes such as earnings quality (Krishnan and Parsons, 2008), earnings management (Srinidhi et al., 2011), stock price informativeness (Gul et al., 2011), and analysts' earnings forecast accuracy (Gul et al., 2013) suggests that board diversity adds to the transparency of financial reports and reduces information asymmetry.

More recent empirical research also suggests that board gender diversity may affect reporting quality, compliance and ethical behaviour. Bear et al. (2010), Hafsi and Turgut (2013) and Harjoto et al. (2014) for instance provide evidence of a link between gender diversity and corporate social responsibility. Bear et al. (2010) find that an increase in the number of female directors on boards is associated with an increase in corporate social responsibility ratings. Liao et al. (2015) find a positive association between percentage of female directors on boards and voluntary disclosure of greenhouse gas emissions.

Recent research on sustainability reporting quality does not consider the effect of corporate governance. Adams and Ferreira (2009) observe female directors appear to have similar impact to that of independent directors. Independent female directors may demand greater sustainability reporting quality. In examining the effect of gender diversity it is important to recognise that gender effects may be subsumed by other board characteristics (Srinidhi et al., 2011). In particular, it is important to investigate if female independent directors have an effect on sustainability reporting quality after controlling for board independence.

\footnotetext{
${ }^{5}$ For example, Campbell and Minguez-Vera (2008) find that existence of women on boards does not in itself affect firm value, but diversity of the board has a positive association with firm value. In contrast to Erhardt et al. (2003), Carter et al. (2010) do not find a significant association between gender diversity and firm performance for a sample of US firms. For a sample of Canadian firms, Francoeur et al. (2008) find that firms with a higher proportion of females on boards and top management positions generate positive and significant abnormal returns. In contrast, using a portfolio approach for a sample of Australian firms, Chapple and Humphrey (2014) do not find an association between diversity and performance.
} 
The above discussion on gender diversity and sustainability reporting quality leads us to posit that gender diverse boards may affect sustainability reporting quality. In this paper we test the following hypotheses:

H1: Female directors have a positive association with sustainability reporting quality.

H2: Independent female directors have a positive association with sustainability reporting quality.

H3: Gender diverse boards have a positive association with sustainability reporting quality.

\section{RESEARCH DESIGN AND DATA}

\section{Model Specification}

To test our hypotheses we use the following model:

$$
\begin{aligned}
\text { SUSQUAL }= & =\alpha+\beta_{1} \mathrm{DIVERSITY}+\beta_{2} \mathrm{BODSIZE}+\beta_{3} \mathrm{BODIND}+\beta_{4} \mathrm{BODMEET}+\beta_{5} \mathrm{RI}+\beta_{6} \mathrm{RB}+\beta \\
& { }_{7} \mathrm{RE}+\beta_{8} \mathrm{IND}+\varepsilon
\end{aligned}
$$

where:

SUSQUAL $=$ sustainability reporting quality on $0-4$ scale $[0=$ no sustainability reports exist; $1=$ sustainability reports exist; $2=$ sustainability reports exist and the company has a sustainability committee affiliated with the board of directors; $3=$ sustainability reports exist and assurance is provided by a non-audit firm; $4=$ sustainability reports exists and is externally assured by a one of the Big 4 or other audit firm]

DIVERSITY $=$ board gender DIVERSITY measured using FIVE alternatives: $B O D F E M=$ number of female directors on board; PRFEM= proportion of female directors on board; $B O D I N D F E M=$ number of independent female directors on board; SHANNON= Shannon index of diversity $\left[=-\sum n_{i=1} P_{i} \ln \left(P_{i}\right)\right.$ where Pi is the percentage of board members in each category (two: male/female) and $\mathrm{n}$ is the total number of board members] $B L A U=$ Blau index of diversity $\left[=1-\sum n_{i=1} P_{i}^{2}\right.$ where $P i$ is the percentage of board members in each category (two: male/female) and $\mathrm{n}$ is the total number of board members]

$B O D S I Z E=$ number of directors on the board

$B O D I N D=$ proportion of independent directors on the board

$B O D M E E T=$ number of board meetings held during the year

$R I=$ reporting incentive factor (a single factor reflecting the strength of a firm's reporting incentives from various firm characteristics (i.e. size, leverage, return on assets, book to market ratio, percent of closely held shares, and percent of foreign sales) 


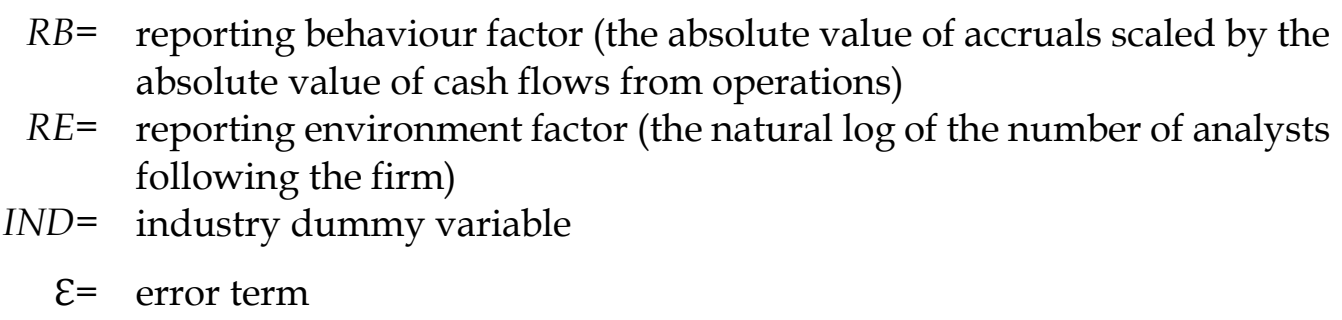

\section{Data and Variables}

In examining the effect of board gender diversity on sustainability reporting quality we rely on a number of alternative measures of diversity. We also focus on the quality of sustainability reporting using a coding scale based on four thresholds, i.e. using a score of $0-4$ to provide an indicator of the quality of information disclosed in these reports. The scores are: $0=$ if sustainability reports do not exist; 1 = if sustainability reports exist; $2=$ if sustainability reports exist and the company has a sustainability committee affiliated with the board of directors; $3=$ if sustainability reports exist and assurance is provided by a non-audit firm); $4=$ if sustainability reports exist and are assured by one of the Big 4 or other audit firm. For the purpose of additional analysis, we also apply other measures of sustainability quality, i.e. we use ASSURANCE which is a dummy variable equal to 1 if sustainability reports are externally assured and 0 otherwise and COMMITTEE which is a dummy variable equal to 1 if a sustainability committee exists and 0 otherwise. ${ }^{6}$

We measure gender diversity using five alternative measures to check the robustness of our findings. They are: the number of female directors on board (BODFEM), proportion of female directors on board (PRFEM), number of independent female directors on board (BODINDFEM), Blau (BLAU) and Shannon (SHANNON) indices of diversity. ${ }^{7}$

We recognise the importance of controlling for corporate governance (Srinidhi et al., 2011; Zaman et al., 2011) in testing the effect of board gender diversity on sustainability

\footnotetext{
${ }^{6}$ Our focus on reporting quality thus contrasts with Liao et al. (2015) who use a dummy measure of whether a firm discloses its participation in the greenhouse gas emission project.

7 We have calculated Shannon and Blau indices following Campbell and Minguez-Vera (2008).
} 
reporting quality. Prior literature suggests that larger boards are more likely to be diverse and have directors from different backgrounds, and that this in turn may lead to the company paying greater attention to sustainability issues (De Villiers et al., 2011). We include board size (BODSIZE) measured by the total number of directors on board. Similarly, selection of a greater number of independent directors is associated with a reduction in agency costs, increased legitimacy and greater interest in sustainability (Arora and Dharwadkar, 2011). We thus include board independence (BODIND) defined as the proportion of outside directors to the total number of directors on the board. The number of board meetings held in a year can affect the level of transparency and quality of the information disclosed as well as the effectiveness of board decision making (Laksmana, 2008; Liao et al., 2015). We include number of board meetings (BODMEET) as another governance variable. ${ }^{8}$

Sustainability reporting quality may be affected by some underlying reporting incentives and reporting behaviour factors. Unlike studies such as Ball et al. (2003), Leuz et al. (2003) and Burgstahler et al. (2006) which focus on cross-country institutional differences as a driver of reporting incentives, Daske et al. (2013) investigate within-country reporting incentives based on a firm level approach. Following Daske et al. (2013: 498), we construct three proxies to identify factors that determine firms' incentives for reporting and factors that reflect firms' actual behaviour. The first proxy is input based and captures firm characteristics affecting management reporting incentives (RI). These are: firm size (natural log of total assets), profitability (return on assets), financial leverage (debt to total assets ratio), growth opportunities (book-to-market ratio), ownership concentration (percentage of closely-held shares), and internationalization (foreign sales over total sales). We use factor analysis to summarise the incentive effects from these firm characteristics and extract a single factor.

\footnotetext{
${ }^{8}$ We also controlled for CEO duality but this variable was dropped from the regression due to lack of statistical variations in its value across firms: $96.58 \%$ of firms in our sample do not have duality role whereas $3.42 \%$ do.
} 
Factor analysis technique helps in constructing a single factor indicating the strength of a firm's reporting incentives from various firm characteristics (Daske et al., 2013). We then compute the level of a firm reporting incentive in year $t$ as the rolling average of the raw factor scores over the year $t$ to $t-2$. Higher values denote greater reporting incentives. We expect firms with bigger size, larger profit, larger financing needs, more growth opportunities, more concentrated ownership structure and greater internationalisation to be associated with higher sustainability reporting quality.

We also use output based proxies to capture the reporting behaviour of firms and their external reporting environment. We capture firm reporting behaviour (RB) using an accrualbased proxy for earnings quality. We measure firm reporting behaviour following Daske et al. (2013) as the absolute value of accruals scaled by the absolute value of cash flows from operations. We then compute the level of firm reporting behaviour in year $t$ as the rolling average of the raw measures over the year $t$ to $t-2$. We multiply the metric by -1 so that higher values denote less earning management and more transparent reporting. We also capture the external reporting environment (RE) using the number of analysts following the firm. We then compute the level of a firm's reporting environment in year $t$ as the rolling average of the natural $\log$ of annual number of analysts (plus one) over the years $t$ to $t-2$. Higher values denote more external pressures from analysts (Daske et al., 2013). ${ }^{9}$

Finally, we control for industry classification (IND) using the DataStream industry classification benchmark (ICB) level 1 industries (ten groups). Our study is based on an initial sample of all the companies listed in 2012 in the UK FTSE350. Elimination of companies with missing data reduces the sample size to 333 firms. The Global Reporting Initiative database is the main source for our dependent variable. We supplemented it with information extracted

\footnotetext{
9 Following Daske et al. (2013) we set analyst following to zero when firms do not have coverage in I/B/E/S database.
} 
from the 2012 annual reports of the sample firms. We relied on annual reports for data on corporate governance variables and sourced data on financial variables from DataStream.

\section{RESULTS AND ANALYSIS}

\section{Descriptive Statistics}

Descriptive statistics for the variables used in the analysis are shown in Table 1. We report the mean and distributional characteristics for each of the variables used in our analysis. Panel A shows the distribution of the dependent variable. It shows that $173(51.95 \%)$ firms do not publish sustainability reports whereas 160 (48.04\%) firms do. There are 51 firms (15.32\%) that have their sustainability reports externally assured by a Big 4 or other audit firm. These firms may be considered higher quality in terms of sustainability reporting.

Table 1 Panel B provides the descriptive statistics for the variables used in our model. The mean sustainability quality score (SUSQUAL) is 1.114 . We also find that $17.4 \%$ of our sample companies have their sustainability reports externally assured by either an audit firm or a non-audit firm and $36 \%$ have a separate committee with responsibility for sustainability reporting. With regard to board gender diversity, we find the number of female directors on boards (BODFEM) ranges from 0-5 with a mean of 1.435 while the mean value of independent female directors on boards (BODINDFEM) is 1.205. The percentage of female directors on boards (PRFEM) is 14.1\%. This is higher than the 9.2\% reported in Liao et al. (2015) for their sample of 2011 CDP FTSE350 firms and indicates that there has been an increase in the proportion of female directors on boards in 2012 compared to 2011, consistent with recent trends in the UK (Davies Report, 2015). The other two proxies for board gender diversity, i.e. the Blau and Shannon indices, have a mean of 0.348 and 0.218 respectively which is higher than the 0.053 (for Blau) and 0.089 (for Shannon) reported by Campbell and Minguez-Vera. (2008) for a sample of firms listed on the continuous market in Spain during 1995-2000. 
In terms of governance characteristics, we find the mean board size (BODSIZE) is 9.336. This is similar to Liao et al. (2015) who reported a mean of 9.0 directors. Independent directors (BODIND) account for $51 \%$ of board members which means that half of the board members are independent. Our finding is lower than the $54.5 \%$ mean reported by Liao et al. (2015) and the $58 \%$ mean reported by Zaman et al. (2011). The mean number of board meetings is 8.18. It is close to the mean of 8.78 reported by Zaman et al. (2011) and 8.4 reported by Liao et al. (2015). The mean for firm reporting incentive (RI) is 0.006 , reporting behaviour (RB) is 2.835 , and reporting environment (RE) is 3.233.

Table 1 Panel C reports mean values of key variables by industry. We find that the basic materials industry has the highest score for sustainability reporting quality followed by utilities, consumer goods, and oil and gas. The financials industry has the lowest score of 0.537. The basic materials industry also has the highest mean for ASSURANCE, i.e. $48 \%$ of firms within this category have their sustainability reports externally assured. This contrasts with the financial industry which has a mean of $1 \%$. We also find that consumer goods industry has the highest mean of 0.625 for COMMITTEE, i.e. existence of a sustainability committee, whereas financials have the lowest mean of 0.21 . With regard to board gender diversity, we find that the utilities industry has the highest mean for: proportion of female directors on boards (PRFEM=0.184), number of independent female directors on boards (BODINDFEM=1.714), Blau index (mean of 0.468) and Shannon index (mean of 0.295).

Table 1 Panel D presents descriptive statistics for diversity when we split our sample into three groups: firms with zero female directors on the board, firms with one female director on the board and firms with more than one female director on the board. The panel shows $75(22.522 \%)$ firms do not have any female directors, 113 (33.933\%) firms have one female director and 145 (43.543\%) firms have more than one female director on their boards. UK companies seem to be more gender diverse when compared, for example, with Australian 
ASX300 companies. ${ }^{10}$ Our descriptive statistics show that firms with more than one female director have the highest mean score for sustainability reporting quality (i.e. SUSQUAL=1.298), whereas firms with one female director have a mean of 1.026 and those with no female directors have a mean of 0.844 . We also find that firms that have one female director (mean BODMEET=8.354) or more than one female director (mean BODMEET=8.344) on the board have more active boards than the ones with no female director (mean BODMEET $=7.372$ ) on the board, larger board size (mean BODSIZE=10.572) and highest proportion of independent directors on the board (mean BODIND $=0.547$ ) than firms without a female director.

[Table 1 about here]

Table 2 shows the correlation matrix for variables used in our analysis. We find that sustainability reporting quality (SUSQUAL) has a positive and significant association with gender diversity (BODFEM in Panel A and BODINDFEM in Panel B), board size (BODSIZE), board meetings (BODMEET), reporting incentive (RI), reporting behaviour (RB) and reporting environment (RE). $\cdot{ }^{11}$ Overall, the correlations are consistent with the hypothesised relationship between board gender diversity and sustainability reporting quality. Table 2 shows no correlation above 0.5 among the variables of interest, therefore multicollinearity is not an issue.

[Table 2 about here]

\section{Empirical Tests and Findings}

\footnotetext{
${ }^{10}$ Chapple and Humphrey (2014) find only $52 \%$ of the 288 companies in their sample of ASX300 listed companies in 2011 had at least one female director.

11 We also run correlations using other measures of gender diversity i.e. PRFEM, BLAU, and SHANNON. The results, not tabulated, are generally consistent with those in Table 2.
} 
Table 3 shows the results for our hypotheses relating to the impact of gender diversity on sustainability reporting quality. The main regression model is run in parts. Panel A Table 3 shows the regressions for the full sample. Models 3.1-3.5 test the impact of gender diversity on sustainability reporting quality (SUSQUAL) using different measures of diversity. We use ordered-Probit specification for the analysis because the dependent variable (SUSQUAL) represents a 0-4 ascending scale variable. ${ }^{12}$ Models 3.6-3.10 repeat the tests after dropping the correlated variable BODSIZE.

To test hypothesis 1 we use the number of female directors on boards (Model 3.1) and proportion of female directors on boards (Model 3.2). To test our second hypothesis we use number of independent female directors on boards (model 3.3). Models 3.4 and 3.5 test hypothesis 3 and use Blau and Shannon indices of diversity. Results show a marginal significant impact of gender diversity on sustainability reporting quality (Models 3.1 and 3.3) but this is largely affected by the correlated variable BODSIZE.

When we drop correlated variable board size, we find variables measuring gender diversity are significant and positive at the 1\% level (Models 3.6 and 3.8). The coefficient of BODINDFEM (Model 3.3 and 3.8) is slightly higher than the coefficient for BODFEM (Model 3.1 and 3.6) suggesting that the effect of independent female directors on sustainability reporting quality is greater than that of female directors. Models 3.9 and 3.10 test hypothesis 3, i.e. the impact of Blau and Shannon indices of diversity on sustainability reporting quality. We obtain similar results for both indices (both significant at $5 \%$ level) indicating a positive and significant impact on sustainability reporting quality. ${ }^{13}$ Board size (BODSIZE) is positive

\footnotetext{
12 We note this contrasts with Liao et al. (2015) who use Probit analysis with their dependent variable as a dummy indicator for whether a firm disclosed participation in the carbon emission project. In our further analysis when we focus on sustainability assurance and on sustainability committee we use logit analysis.

${ }^{13}$ Although as shown in Table 2 the magnitude of pairwise correlations among BODSIZE and other variables are not greater than 0.5, we identify that the correlation between BODFEM and BODSIZE is 0.486 and between BODINDFEM and BODSIZE is 0.465 which may be considered as relatively high. To alleviate this potential multicollinearity problem, we followed the method suggested by Choi et al.
} 
and significant in all models, and provides evidence of large boards affecting the quality of sustainability reporting. ${ }^{14}$ We also find reporting incentives (RI) has a significant and positive association with sustainability reporting quality in all models, and reporting environment (RE) has a significant and positive association with sustainability reporting quality in most models. This is consistent with the idea that these proxies capture incentives for more transparent reporting. Their significant impact increases when we drop the correlated variable BODSIZE. Reporting behaviour (RB) is not significant in the regression models but industry sectors have a positive association with sustainability reporting quality. The association is significant for oil and gas, basic materials, industrials and consumer goods industries.

We divide the sample into small size firms and big size firms based on median ${ }^{15}$ to check whether our results are impacted by the size factor. Splitting the sample into small and large sized firms assists in analysing the effect of gender on sustainability reporting quality beyond any size effect. In Table 3 Panel B we report the results for small firms (Models 3.113.15) and for large firms (Models 3.16-3.20). Our results for the sample of small firms show that gender diversity measured by the five alternative measures are all positive and have a significant association with sustainability reporting quality. For the small firms subsample reporting incentive (RI) is positive and significant in all models. The results are similar for large firms (Models 3.16-3.20) - all gender diversity measures have a positive association with sustainability reporting quality, although only BODFEM and BODINDFEM are significant.

[Table 3 about here]

(2008) by repeating the analysis after excluding correlated variables. We also use residuals obtained from regressing BODSIZE on BODFEM and BODINDFEM to replace the raw data of BODSIZE. Our findings (untabulated) are qualitatively similar to the original ones.

14 This is consistent with Liao et al. (2015) who find larger boards are associated with disclosure of a firm's participation in the carbon emission project. It is also consistent with De Villiers et al. (2011) who observe that larger boards are more likely to be diverse and include directors from different background and interests including corporate social responsibility.

${ }^{15}$ We measure size using total assets. 


\section{Additional Analysis}

In Table 4 we report the results when we include board size as a categorical variable in the main regression model along with explanatory variables to investigate the impact of different levels of board size. ${ }^{16}$ Following Gelman and Park (2009) we divide BODSIZE into four-level categories. ${ }^{17}$ The percentage of firms with BODSIZE of up to 7 directors is $12.61 \%(n=42), 8-10$ directors is $42.04 \%(\mathrm{n}=140), 11-14$ directors is $37.53 \%(\mathrm{n}=125)$, and $15-21$ directors is $7.80 \%$ $(\mathrm{n}=26){ }^{18}$ (untabulated). Results show that gender diversity measured by BODFEM, BODINDFEM, BLAU and SHANNON indices have a significant and positive association with sustainability reporting quality. ${ }^{19}$ We thus find additional support for our hypotheses that gender diverse boards have a positive significant association with sustainability reporting quality.

[Table 4 about here]

We also use alternative measures of sustainability reporting quality, i.e. ASSURANCE and COMMITTEE, to assess the robustness of our findings. Both measures are dummy variables and thus we use a logit specification test. In the models reported in Table 5 we use

\footnotetext{
16 We follow Gelman and Park (2009) who argue that discretization can be beneficial in helping the communication of regression results. Although discretization can lead to some information loss, this can be reduced by choosing the cut-off points adaptively ( $\mathrm{O}^{\prime}$ Brien, 2004).

${ }^{17}$ Choosing cut-off points 7, 10, 14, and 21 enables us to estimate the optimum partition from the data $\left(\mathrm{O}^{\prime}\right.$ Brien, 2004) and reduce generated missing values.

18 The choice of an optimal cut-off point is determined from the training set. This is approached by trying more than one value and choosing that which in some sense gives the most satisfactory results. In practice, the search may be restricted to the central 80 or $90 \%$ of observations (which explains the existence of missing values). Moreover, we need to look at the Ns of subcategories and make sure they are not too small. If the Ns in some subcategories are too small, we might need to combine some adjacent categories because cut-off points that do not satisfactory differ from each other might be problematic.

${ }^{19}$ We also divided BODSIZE into $25 \%, 50 \%$ and $75 \%$ quartiles. The results are consistent with those based on cut-off points used following O'Brien (2004).
} 
ASSURANCE as a measure of sustainability reporting quality. We find gender diversity measured using both the number of female directors on boards and number of independent female directors on boards has a positive and significant association with ASSURANCE, i.e. whether a company's sustainability report is externally assured (Table 5).

When we use COMMITTEE, the existence of sustainability committee, we find all our measures of gender diversity (i.e. BODFEM, PRFEM, BODINDFEM, BLAU and SHANNON) are significant and positive (see Table 6). Overall, the results are consistent with our main findings and provide additional support for the hypothesised relationship between board gender diversity and sustainability reporting quality. ${ }^{20}$

[Table 5 and 6 about here]

\section{SUMMARY AND CONCLUSIONS}

This paper examines the relationship between board gender diversity and sustainability reporting quality. It investigates whether gender diversity measured using five alternative measures (i.e. number of female directors on board, the proportion of female directors on board, number of independent female directors on board; and the Shannon and Blau indices of diversity) is associated with higher sustainability reporting quality. The paper also investigates if governance factors, i.e. board size, board meetings and board independence, are associated with sustainability reporting quality. Additionally, following Daske et al. (2013) we control for reporting incentives, reporting behaviour, and reporting environment which

\footnotetext{
${ }^{20}$ As an additional test we also follow the portfolio approach adopted in Chapple and Humphrey (2014) and split our firms into three subsamples: firms with no female director; firms with one female director and firms with more than one female director. Chapple and Humphrey (2014) suggest that splitting a sample into portfolios helps in mitigating issues arising from omitted variables, heterogeneity, and simultaneous issues among variables. Our untabulated results are consistent with our main findings and support our hypothesis that board gender diversity affects sustainability reporting quality. The effect is most pronounced for the more than one female director subsample.
} 
may affect sustainability reporting. We proxy for sustainability reporting quality using a score system where the absence of sustainability reporting has the lowest score and sustainability reports that are independently assured by one of the Big 4 or other audit firm have the highest score.

Using a sample of all companies listed in 2012 in the UK FTSE350 and applying different empirical tests dealing with correlated variables, heterogeneity and omitted variables issues, and after controlling for corporate governance as well as firm incentives, firm behaviour and firm environment, we find that board gender diversity has a positive and significant association with sustainability reporting quality. Our analysis also shows that reporting incentives (RI) has a significant and positive association with sustainability reporting quality. Dividing the sample into small and large sized firms enables us to examine the impact of gender diversity beyond any size effects. We find all our board gender diversity measures are significant for the small sized sample whereas in the large sized sample all the gender diversity measures have a positive association with sustainability reporting quality although only BODFEM and BODINDFEM are significant. Additional tests dealing with board size correlated effects by applying categorisation of board size show that gender diversity has a significant and positive association with sustainability quality reporting in most models. Sensitivity tests using alternative measures of sustainability reporting quality (i.e. whether the report is externally assured and whether the company has a sustainability committee) are also consistent with our main findings.

Our paper has a few limitations. The findings are restricted to companies listed in 2012 in the UK FTSE350 and thus are relatively large, but do account for a significant proportion of companies based on market value. Since corporate governance and board gender diversity recommendations vary internationally, further research examining the effect of board gender diversity on the quality of reporting, including their impact on decisions relating to sustainability and assurance, in different institutional and regulatory contexts would make 
valuable contribution to the literature. Moreover, our paper focuses on the association between board gender diversity and sustainability reporting quality and not on causation. Future research would benefit from a focus on the black box of governance (Turley and Zaman, 2007; Nielsen and Huse, 2010; Ben-Amar et al., 2013) and examining the process via which board diversity affects reporting quality and the costs and benefits of sustainability reporting (Simnett and Huggins, 2015).

Overall, the analysis in our paper provides evidence of gender diverse boards having a positive significant association with sustainability reporting quality. This is consistent with the view that female representation on boards of directors affects the quality of corporate reporting. Our findings are underpinned by detailed testing of model specification and sensitivity analysis, including tests dealing with size confounding effects and correlation among variables. Our study has important implications for policy making. It provides evidence on the effect of the voluntary softer comply or explain approach (Adams, 2015), as opposed to the mandatory quota used in many countries, towards encouraging board gender diversity on sustainability reporting quality. Our results contribute to the growing body of literature highlighting the importance of board diversity and governance when considering sustainability reporting and assurance issues at the firm level. 


\section{REFERENCES}

Adams, R. 2015. Myths and Facts about Female Directors. Washington: International Finance Corporation.

Adams, R., \& Ferreira, D. 2009. "Women in the boardroom and their impact on governance and performance". Journal of Financial Economics, 94(2), 291-309.

Adams, R., \& Funk, P. 2012. “Beyond the glass ceiling: does gender matter?" Management Science, 58(2), 219-235.

Adams, R., de Haan, J., Terjesen, S., \& van Ees, H. 2015. “Board diversity: moving the field forward". Corporate Governance: An International Review, 23(2), 77-82.

Arora, P., \& Dharwadkar, R. 2011. “Corporate governance and corporate social responsibility (CSR): The moderating roles of attainment discrepancy and organization slack". Corporate Governance: An International Review, 19(2), 136-152.

Ball, R., Robin, A., \& Wu, J. S. 2003. “Incentives versus standards: properties of accounting income in four East Asian countries". Journal of Accounting and Economics, 36(1), 235270.

Bear, S., Rahman, N., \& Post, C. 2010. “The impact of board diversity and gender composition on corporate social responsibility and firm reputation". Journal of Business Ethics, 97(2), 207-221.

Ben-Amar, W., Francoeur, C., Hafsi, T., \& Labelle, R. 2013. “What makes better boards? A closer look at diversity and ownership". British Journal of Management, 24(1), 85-101.

Burgstahler, D. C., Hail, L., \& Leuz, C. 2006. “The importance of reporting incentives: Earnings management in European private and public firms". The Accounting Review, 81(5), 9831016.

Campbell, K., \& Mínguez-Vera, A. 2008. “Gender diversity in the boardroom and firm financial performance". Journal of Business Ethics, 83 (3), 435-451. 
Capezio, A. \& Mavisakalyan, A. 2015. "Women in the boardroom and fraud: Evidence from Australia". Australian Journal of Management, 1-16.

Carter, D., D'Souza, F., Simkins, B., \& Simpson, W. 2010. “The gender and ethnic diversity of US boards and board committees and firm financial performance". Corporate Governance: An International Review, 18(5), 396-414.

Carter, D., Simkins, B., \& Simpson, W. G. 2003. “Corporate governance, board diversity, and firm value". Financial Review, 38(1), 33-53.

Chapple, L., \& Humphrey, J. E. 2014. “Does board gender diversity have a financial impact? Evidence using stock portfolio performance". Journal of Business Ethics, 122(4), 709-723.

Choi, J. H., Kim, J. B., Liu, X., \& Simunic, D. A. 2008. “Audit pricing, legal liability regimes and Big 4 premiums: Theory and cross-country evidence". Contemporary Accounting Research, 25(1), 55-99.

Daske, H., Hail, L., Leuz, C., \& Verdi, R. 2013. “Adopting a label: Heterogeneity in the economic consequences around IAS/IFRS adoptions". Journal of Accounting Research, 51(3), 495-547.

Davies Report. 2011. Women on boards: an independent review into women on boards. Technical Report, Department for Business Innovation and Skills (BIS), London.

Davies Report. 2015. Improving the Gender Balance in British Boards. Women on Boards: London.

De Villiers, C., Naiker, V., \& Van Staden, C.J. 2011. “The effect of board characteristics on firm environmental performance". Journal of Management, 37, 1636-1663.

Erhardt, N.L., Werbel, J.D., \& Shrader, C.B. 2003. "Board of director diversity and firm financial performance". Corporate Governance: An International Review, 11(2), 102-111.

European Commission. 2012. Women in decision-making in the EU. Brussels: European Union. European Commission. 2014. Improving the gender balance in company boardrooms. Brussels: European Union. 
Francoeur, C., Labelle, R., \& Sinclair-Desgagne, B. 2008. “Gender diversity in corporate governance and top management". Journal of Business Ethics, 81(1), 83-95.

Gelman, A., \& Park, D. K. 2009. “Splitting a predictor at the upper quarter or third and the lower quarter or third". The American Statistician, 63(1), 1-8.

GRI [Global Reporting Initiative]. 2013. Sustainability Reporting Guidelines, Boston: GRI.

Gul, F. A., Hutchinson, M., \& Lai, K. M. 2013. “Gender-diverse boards and properties of analyst earnings forecasts". Accounting Horizons, 27(3), 511-538.

Gul, F.A., Srinidhi, B., \& Ng, A.C. 2011. “Does board gender diversity improve the informativeness of stock prices?". Journal of Accounting and Economics, 51(3), 314-338.

Hafsi, T., \& Turgut, G. 2013. “Boardroom diversity and its effect on social performance: Conceptualization and empirical evidence". Journal of Business Ethics, 112(3), 463-479.

Harjoto, M., Laksmana, I., \& Lee, R. 2014. "Board diversity and corporate social responsibility". Journal of Business Ethics, 1-20.

Higgs Report. 2003. Review of the Role and Effectiveness of Non-Executive Directors. London: Department for Trade and Industry.

Hillman, A. J., \& Dalziel, T. 2003. "Boards of directors and firm performance: integrating agency and resource dependence perspectives". Academy of Management Review, 28(3), 383-396.

Hillman, A. J., Cannella, A.A., \& Harris, I. C. 2002. "Women and racial minorities in the boardroom: how do directors differ?". Journal of Management, 28(6), 747-763.

Hodge, K., Subramaniam, N., \& Stewart, J. 2009. “Assurance of sustainability reports: impact on report users' confidence and perceptions of information credibility". Australian Accounting Review, 19(3), 178-194. 
Isidro, H., \& Sobral, M. 2014. "The effects of women on corporate boards on firm value, financial performance, and ethical and social compliance". Journal of Business Ethics, 119.

Junior, R. M., Best, P. J., \& Cotter, J. 2014. “Sustainability reporting and assurance: a historical analysis on a world-wide phenomenon". Journal of Business Ethics, 120(1), 1-11.

KPMG. 2011. KPMG International Study of Corporate Sustainability Reporting. Amsterdam: Graduate Business School.

Krishnan, G. V. \& Parsons, L. M. 2008. “Getting to the bottom line: an exploration of gender and earnings quality". Journal of Business Ethics, 78(1-2), 65-76.

Laksmana, I. 2008. “Corporate board governance and voluntary disclosure of executive compensation practices". Contemporary Accounting Research, 25(4), 1147-82.

Leuz, C., Nanda, D., \& Wysocki, P. D. 2003. “Earnings management and investor protection: an international comparison". Journal of Financial Economics, 69(3), 505-527.

Liao, L., Luo. L., \& Tang, Q. 2015. “Gender diversity, board independence, environmental committee and greenhouse gas disclosure". British Accounting Review, 47(4), 409-424.

Manetti, G., \& Becatti, L. 2009. “Assurance services for sustainability reports: standards and empirical evidence". Journal of Business Ethics, 87(1), 289-298.

Manetti, G., \& Toccafondi, S. 2012. "The role of stakeholders in sustainability reporting assurance". Journal of Business Ethics, 107(3), 363-377.

Miller, T., \& Triana, M. D. C. 2009. “Demographic diversity in the boardroom: Mediators of the board diversity-firm performance relationship". Journal of Management Studies, 46(5), 755-786.

Mock, T. J., Rao, S. S., \& Srivastava, R. P. 2013. “The development of worldwide sustainability reporting assurance". Australian Accounting Review, 23(4), 280-294. 
Mock, T. J., Strohm, C., \& Swartz, K. M. 2007. “An examination of worldwide assured sustainability reporting". Australian Accounting Review, 17(1), 67-77.

Nielsen, S., \& Huse, M. 2010. “The contribution of women on boards of directors: Going beyond the surface". Corporate Governance: An International Review, 18(2), 136-148.

O'Brien, S. M. 2004. “Cutpoint selection for categorizing a continuous predictor". Biometrics, 60(2), 504-509.

Ruhnke, K., \& Gabriel, A. 2013. “Determinants of voluntary assurance on sustainability reports: an empirical analysis". Journal of Business Economics, 83(9), 1063-1091.

Simnett, R. 2012. “Assurance of sustainability reports". Sustainability Accounting, Management and Policy Journal, 3(1), 89-98.

Simnett, R. \& Huggins, A. L. (2015). “Integrated reporting and assurance: where can research add value?" Sustainability Accounting, Management and Policy Journal, 6(1): 29-53.

Simnett, R., Vanstraelen, A., \& Chua, W.F. 2009. “Assurance on sustainability reports: an international comparison". Accounting Review, 84(3), 937-967.

Srinidhi, B., Gul, F. A., \& Tsui, J. 2011. "Female directors and earnings quality". Contemporary Accounting Research, 28(5): 1610-1644.

Terjesen, S., Sealy, R., \& Singh, V. 2009. “Women directors on corporate boards: A review and research agenda". Corporate Governance: An International Review, 17(3), 320-337.

Triana, M. D. C., Miller, T. L., \& Trzebiatowski, T. M. 2013. “The double-edged nature of board gender diversity: Diversity, firm performance, and the power of women directors as predictors of strategic change". Organization Science, 25(2), 609-632.

Turley, S., \& Zaman, M. 2007. “Audit committee process: informal processes and behavioural effects". Accounting, Auditing and Accountability Journal, 20(5), 765-788.

Zaman, M., Hudaib, M., \& Haniffa, R. 2011. “Corporate governance quality, audit fees and non-audit services fees". Journal of Business Finance and Accounting, 38(1-2), 165-197. 
Table 1 Descriptive Statistics

\begin{tabular}{|c|c|c|c|c|c|c|c|c|c|c|c|c|c|c|c|}
\hline \multicolumn{16}{|c|}{ Panel A: Frequency of sustainability quality types } \\
\hline \multicolumn{5}{|c|}{ SUSQUAL Scale } & \multicolumn{2}{|c|}{0} & \multicolumn{2}{|c|}{1} & \multicolumn{2}{|r|}{2} & \multicolumn{2}{|r|}{3} & \multicolumn{3}{|c|}{4} \\
\hline \multicolumn{4}{|c|}{ Number of firms (\% of firms) } & \multicolumn{3}{|c|}{$173(51.95 \%)$} & \multicolumn{2}{|c|}{$63(18.91 \%)$} & \multicolumn{2}{|c|}{$40(12.01 \%)$} & \multicolumn{2}{|c|}{$6(1.80 \%)$} & \multicolumn{3}{|c|}{$51(15.32 \%)$} \\
\hline & $\mathrm{N}$ & SUSQUAL & ASS & COMM & BODFEM & PRFEM & BODINDFEM & BLAU & SHANNON & BODSIZE & BODIND & BODMEET & RI & $\mathrm{RB}$ & $\mathrm{RE}$ \\
\hline \multicolumn{16}{|c|}{ Panel B: All firms } \\
\hline Mean & 333 & 1.114 & 0.174 & 0.36 & 1.435 & 0.141 & 1.205 & 0.348 & 0.218 & 9.336 & 0.51 & 8.187 & 0.006 & -2.835 & 3.233 \\
\hline Median & 333 & 0 & 0 & 0 & 1 & 0.142 & 1 & 0.41 & 0.244 & 9 & 0.571 & 8 & 0.025 & -0.571 & 3.663 \\
\hline Std.Dev. & 333 & 1.472 & 0.379 & 0.48 & 1.012 & 0.104 & 0.929 & 0.213 & 0.143 & 2.656 & 0.275 & 2.723 & 0.496 & 9.237 & 1.257 \\
\hline Maximum & 333 & 4 & 1 & 1 & 5 & 0.571 & 5 & 0.69 & 0.5 & 21 & 1 & 20 & 1.239 & -0.016 & 4.744 \\
\hline Minimum & 333 & 0 & 0 & 0 & 0 & 0 & 0 & 0 & 0 & 4 & 0 & 2 & -1.178 & -66.469 & 0 \\
\hline \multicolumn{16}{|l|}{ Panel C: Industry } \\
\hline Oil \& Gas & 18 & 1.438 & 0.333 & 0.277 & 1.188 & 0.097 & 1.063 & 0.287 & 0.168 & 10.438 & 0.531 & 8.125 & -0.126 & -1.219 & 3.835 \\
\hline Basic Materials & 29 & 2.833 & 0.482 & 0.482 & 0.875 & 0.07 & 0.667 & 0.192 & 0.116 & 10.125 & 0.562 & 7.75 & -0.099 & $-2 . .597$ & 3.391 \\
\hline Industrials & 66 & 1.115 & 0.166 & 0.424 & 1.328 & 0.135 & 1.082 & 0.353 & 0.218 & 9.279 & 0.508 & 9.016 & -0.126 & -2.315 & 3.494 \\
\hline Consumer Goods & 24 & 1.522 & 0.166 & 0.625 & 1.739 & 0.172 & 1.435 & 0.406 & 0.261 & 9.565 & 0.476 & 8.304 & -0.024 & -0.870 & 3.778 \\
\hline Health Care & 8 & 1.25 & 0.125 & 0.5 & 2 & 0.166 & 2 & 0.388 & 0.253 & 10.625 & 0.568 & 9.75 & -0.087 & -0.303 & 3.827 \\
\hline Consumer Services & 57 & 0.891 & 0.123 & 0.315 & 1.618 & 0.163 & 1.291 & 0.403 & 0.257 & 9.545 & 0.463 & 8.364 & -0.091 & -0.932 & 3.804 \\
\hline Telecommunications & 9 & 1.333 & 0.222 & 0.555 & 2.167 & 0.156 & 1.5 & 0.376 & 0.265 & 9.833 & 0.418 & 8 & 0.186 & -4.466 & 3.687 \\
\hline Utilities & 7 & 1.571 & 0.286 & 0.571 & 1.857 & 0.184 & 1.714 & 0.468 & 0.295 & 10.143 & 0.541 & 8.286 & 0.386 & -0.493 & 3.937 \\
\hline Financials & 100 & 0.537 & 0.009 & 0.21 & 1.476 & 0.152 & 1.207 & 0.36 & 0.228 & 8.902 & 0.565 & 7.451 & 0.215 & -7.233 & 2.264 \\
\hline Technology & 15 & 1.273 & 0.133 & 0.4 & 1.091 & 0.116 & 1 & 0.277 & 0.174 & 7.909 & 0.427 & 9.091 & -0.422 & -0.481 & 3.673 \\
\hline
\end{tabular}
with the board of directors; $3=$ if sustainability reports exist and external assurance is provided by a non-audit firm; $4=$ if sustainability reports exist and external assurance provided by a Big 4 or other audit firm]; ASSURANCE= takes the value of 1 in the case of sustainability being assured and 0 otherwise; COMMITTEE= takes the value of 1 in the case of existence of sustainability committee and 0 otherwise; BODFEM= number of female directors on board; PRFEM= proportion of female directors on board; BODINDFEM= number of independent female directors on board; SHANNON= Shannon index of diversity; BLAU= Blau index of diversity; BODSIZE= number of directors on board; BODIND= proportion of independent directors on board; BODMEET= number of board meetings; Reporting incentives (RI)= A single factor reflecting the strength of firm's reporting incentives from various firm's characteristics (i.e. size, leverage, return on assets, book to market ratio, percent of closely held shares, and percent of foreign sales); Reporting behaviour (RB)= the absolute value of accruals scaled by the absolute value of cash flows from operations; Reporting environment $(\mathrm{RE})=$ the natural log of the number of analysts following the firm. 


\begin{tabular}{|c|c|c|c|c|c|c|c|c|c|}
\hline \multicolumn{10}{|c|}{ Panel D: Number of Female Directors } \\
\hline & $\mathrm{N}$ & $\begin{array}{l}\% \text { of } \\
\text { total }\end{array}$ & SUSQUAL & BODSIZE & BODIND & BODMEET & RI & $\mathrm{RB}$ & $\mathrm{RE}$ \\
\hline \multicolumn{10}{|l|}{$F E M A L E=0$} \\
\hline Mean & 75 & $22.522 \%$ & 0.844 & 7.351 & 0.463 & 7.372 & -0.167 & -8.868 & 2.648 \\
\hline Median & 75 & $22.522 \%$ & 0 & 7 & 0.571 & 7 & -0.149 & -0.646 & 3.044 \\
\hline Std.Dev & 75 & $22.522 \%$ & 1.436 & 1.904 & 0.336 & 2.572 & 0.379 & 9.683 & 1.355 \\
\hline Minimum & 75 & $22.522 \%$ & 0 & 4 & 0 & 2 & -0.955 & -34.807 & 0 \\
\hline Maximum & 75 & $22.522 \%$ & 4 & 13 & 1 & 14 & 0.673 & -0.065 & 4.369 \\
\hline \multicolumn{10}{|l|}{$F E M A L E=1$} \\
\hline Mean & 113 & $33.933 \%$ & 1.026 & 8.973 & 0.481 & 8.354 & 0.013 & -1.811 & 3.160 \\
\hline Median & 113 & $33.933 \%$ & 0 & 9 & 0.538 & 8 & 0.002 & -0.657 & 3.611 \\
\hline Std.Dev & 113 & $33.933 \%$ & 1.435 & 2.225 & 0.271 & 2.868 & 0.501 & 4.170 & 1.259 \\
\hline Minimum & 113 & $33.933 \%$ & 0 & 4 & 0 & 3 & -1.178 & -34.807 & 0 \\
\hline Maximum & 113 & $33.933 \%$ & 4 & 16 & 1 & 18 & 1.239 & -0.016 & 4.454 \\
\hline \multicolumn{10}{|l|}{$F E M A L E>1$} \\
\hline Mean & 145 & $43.543 \%$ & 1.298 & 10.572 & 0.547 & 8.344 & 0.051 & -4.529 & 3.494 \\
\hline Median & 145 & $43.543 \%$ & 1 & 10 & 0.625 & 8 & 0.116 & -0.542 & 3.912 \\
\hline Std.Dev & 145 & $43.543 \%$ & 1.482 & 2.618 & 0.256 & 2.531 & 0.520 & 3.921 & 1.143 \\
\hline Minimum & 145 & $43.543 \%$ & 0 & 5 & 0 & 4 & -1.154 & -66.469 & 0 \\
\hline Maximum & 145 & $43.543 \%$ & 4 & 21 & 1 & 19 & 1.115 & -0.01 & 4.744 \\
\hline
\end{tabular}

FEMALE $=0$ denotes firms with no females on the board; FEMALE=1 firms with one female director on the board; FEMALE $>1$ firms with more than one female on the board. SUSQUAL= sustainability report quality based on 0-4 scale [i.e. $0=$ no existence of sustainability report; $1=$ if sustainability reports exist; $2=$ if sustainability reports exist and the company has a sustainability committee affiliated with the board of directors; $3=$ if sustainability reports exist and external assurance is provided by a non-audit firm; $4=$ if sustainability reports exist and external assurance provided by a Big 4 or other audit firm]; BODSIZE= number of directors on board; BODIND= proportion of independent directors on board; BODMEET= number of board meetings; Reporting incentives $(\mathrm{RI})=\mathrm{A}$ single factor reflecting the strength of firm's reporting incentives from various firm's characteristics (i.e. size, leverage, return on assets, book to market ratio, percent of closely held shares, and percent of foreign sales); Reporting behaviour $(\mathrm{RB})=$ the absolute value of accruals scaled by the absolute value of cash flows from operations; Reporting environment $(\mathrm{RE})=$ the natural log of the number of analysts following the firm. 
Table 2 Correlation Matrix

\begin{tabular}{lllllllll}
\hline & SUSQUAL & BODFEM & BODSIZE & BODIND & BODMEET & RI & RB & RI \\
\hline \multicolumn{2}{l}{ Panel A: Gender measured by BODFEM } & & & & & \\
\hline SUSQUAL & 1.000 & & & & & & & \\
BODFEM & $0.170^{* * *}$ & 1.000 & & & & & & \\
BODSIZE & $0.351^{* * *}$ & $0.486^{* * *}$ & 1.000 & & & & & \\
BODIND & $0.115^{* *}$ & $0.115^{* *}$ & $0.101^{*}$ & 1.000 & & & & \\
BODMEET & $0.147^{* * *}$ & 0.058 & $0.196^{* * *}$ & -0.004 & 1.000 & & & \\
RI & $0.197^{* * *}$ & 0.220 & 0.177 & 0.126 & 0.041 & 1.000 & & \\
RB & $0.130^{* *}$ & $0.108^{*}$ & $0.140^{* *}$ & 0.006 & $0.101^{*}$ & $-0.360^{* * *}$ & 1.000 & \\
RE & $0.381^{* * *}$ & $0.372^{* * *}$ & $0.494^{* * *}$ & $0.168^{* * *}$ & $0.197^{* * *}$ & $0.168^{* * *}$ & $0.271^{* * *}$ & 1.000
\end{tabular}

Panel B: Gender measured by BODINDFEM

\begin{tabular}{|c|c|c|c|c|c|c|c|c|}
\hline SUSQUAL & 1.000 & & & & & & & \\
\hline BODINDFEM & $0.188^{* * *}$ & 1.000 & & & & & & \\
\hline BODSIZE & $0.344^{* * *}$ & $0.465^{* * *}$ & 1.000 & & & & & \\
\hline BODIND & $0.104^{* * *}$ & $0.209^{* * *}$ & $0.090^{* * *}$ & 1.000 & & & & \\
\hline BODMEET & $0.142^{* *}$ & 0.069 & $0.191^{* * *}$ & -0.019 & 1.000 & & & \\
\hline RI & $0.201^{* * *}$ & $0.272^{* * *}$ & $0.174^{* * *}$ & $0.127^{* *}$ & 0.038 & 1.000 & & \\
\hline $\mathrm{RB}$ & $0.120^{* *}$ & $0.098^{*}$ & $0.131^{* *}$ & -0.012 & 0.085 & $-0.368^{* * *}$ & 1.000 & \\
\hline RE & $0.378^{* * *}$ & $0.396^{* * *}$ & $0.491^{* * *}$ & $0.155^{* * *}$ & $0.181^{* * *}$ & $0.166^{* * *}$ & $0.256^{* * *}$ & 1.000 \\
\hline
\end{tabular}

SUSQUAL= sustainability report quality based on 0-4 score; BODFEM= number of female directors on board; BODINDFEM= number of independent female directors on board; BODSIZE $=$ number of directors on board; BODIND= proportion of independent directors on board; BODMEET= number of board meetings; Reporting incentives $(\mathrm{RI})=\mathrm{A}$ single factor reflecting the strength of firm's reporting incentives from various firm's characteristics (i.e. size (total asset), leverage, return on assets, book to market ratio, percent of closely held shares, and percent of foreign sales); Reporting behaviour $(\mathrm{RB})=$ the absolute value of accruals scaled by the absolute value of cash flows from operations; Reporting environment $(\mathrm{RE})=$ the natural log of the number of analysts following the firm. 
Table 3 Sustainability Reporting Quality and Gender Diversity

\begin{tabular}{|c|c|c|c|c|c|c|c|c|c|c|}
\hline Panel A: All firms ( $n=3$ & & & & & & & & & & \\
\hline$D V=S U S Q U A L$ & $\begin{array}{c}\text { Model } \\
3.1\end{array}$ & $\begin{array}{c}\text { Model } \\
3.2 \\
\end{array}$ & $\begin{array}{c}\text { Model } \\
3.3 \\
\end{array}$ & $\begin{array}{c}\text { Model } \\
3.4\end{array}$ & $\begin{array}{c}\text { Model } \\
3.5\end{array}$ & $\begin{array}{c}\text { Model } \\
3.6 \\
\end{array}$ & $\begin{array}{c}\text { Model } \\
3.7 \\
\end{array}$ & $\begin{array}{c}\text { Model } \\
3.8 \\
\end{array}$ & $\begin{array}{c}\text { Model } \\
3.9 \\
\end{array}$ & $\begin{array}{c}\text { Model } \\
3.10 \\
\end{array}$ \\
\hline BODFEM & $0.137^{*}$ & & & & & $0.239 * * *$ & & & & \\
\hline PRFEM & & 0.588 & & & & & 0.933 & & & \\
\hline BODINDFEM & & & $0.154^{*}$ & & & & & $0.258^{* * *}$ & & \\
\hline BLAU & & & & 0.576 & & & & & $0.971^{* *}$ & \\
\hline SHANNON & & & & & 0.351 & & & & & $0.678^{* *}$ \\
\hline BODSIZE & $0.099^{* *}$ & $0.112^{* * *}$ & $0.098^{* * *}$ & $0.108^{* * *}$ & $0.108^{* * *}$ & & & & & \\
\hline BODIND & 0.095 & 0.12 & 0.043 & 0.123 & 0.128 & 0.175 & 0.234 & 0.039 & 0.230 & 0.232 \\
\hline BODMEET & 0.034 & 0.015 & 0.035 & 0.015 & 0.015 & 0.041 & 0.015 & 0.043 & 0.016 & 0.016 \\
\hline RI & $0.582^{* *}$ & $0.572^{* * *}$ & $0.572^{* * *}$ & $0.573^{* * *}$ & $0.568^{* * *}$ & $0.626^{* * *}$ & $0.668^{* * *}$ & $0.586^{* * *}$ & $0.664^{* * *}$ & $0.656^{* * *}$ \\
\hline RB & -0.006 & -0.005 & -0.005 & -0.006 & -0.006 & -0.006 & -0.002 & -0.005 & -0.002 & -0.002 \\
\hline RE & $0.195^{*}$ & $0.211^{*}$ & 0.191 & $0.212^{*}$ & $0.211^{*}$ & $0.291^{* *}$ & $0.334^{* * *}$ & $0.273^{* *}$ & $0.327^{* * *}$ & $0.323^{* * *}$ \\
\hline Oil \& Gas & $1.027^{* *}$ & $0.862^{* * *}$ & $1.010^{* * *}$ & $0.867^{* *}$ & $0.856^{* *}$ & $0.979 * * *$ & $0.759^{* *}$ & $0.967^{* * *}$ & $0.773^{* * *}$ & $0.766^{* *}$ \\
\hline Basic Materials & $2.148^{* *}$ & $1.841^{* * *}$ & $2.147^{* * *}$ & $1.861^{* * *}$ & $1.853^{* * *}$ & $2.115^{\star * *}$ & $1.732^{* * *}$ & $2.145^{\star * *}$ & $1.771^{* * *}$ & $1.778^{\star * *}$ \\
\hline Industrials & $0.803^{* *}$ & $0.676^{* * *}$ & $0.819^{* * *}$ & $0.675^{* * *}$ & $0.670^{* * *}$ & $0.704^{* * *}$ & $0.540^{* *}$ & $0.705^{* * *}$ & $0.545^{\star *}$ & $0.542^{* *}$ \\
\hline Consumer Goods & $1.081^{* *}$ & $0.992^{* * *}$ & $1.085^{* * *}$ & $0.985^{* * *}$ & $0.987^{* * *}$ & $0.953^{* * *}$ & $0.817^{* * *}$ & $0.938^{* * *}$ & $0.816^{* * *}$ & $0.821^{* * *}$ \\
\hline Health Care & 0.631 & 0.589 & 0.58 & 0.586 & 0.591 & 0.546 & 0.535 & 0.461 & 0.533 & 0.543 \\
\hline Consumer Services & 0.363 & 0.265 & 0.372 & 0.257 & 0.267 & 0.222 & 0.089 & 0.231 & 0.083 & 0.094 \\
\hline Telecommunication & $0.671^{*}$ & $1.039^{* *}$ & 0.558 & $1.116^{* *}$ & $1.116^{* *}$ & 0.528 & 0.698 & 0.394 & $0.809^{*}$ & 0.813 \\
\hline Utilities & $0.707^{*}$ & 0.606 & 0.684 & 0.591 & 0.592 & $0.579 *$ & 0.437 & 0.546 & 0.421 & 0.419 \\
\hline Technologies & $1.136^{* *}$ & $0.956^{* *}$ & $1.110^{\star * *}$ & $0.951^{* *}$ & $0.948^{* *}$ & $0.863^{* *}$ & $0.622^{*}$ & $0.864^{* *}$ & 0.633 & $0.637^{*}$ \\
\hline Pseudo $\mathrm{R}^{2}$ & 0.159 & 0.145 & 0.145 & 0.157 & 0.145 & 0.151 & 0.133 & 0.147 & 0.135 & 0.134 \\
\hline Wald $\chi^{2}$ & 91.25 & 94.38 & 88.61 & 94.54 & 94.06 & 81.65 & 73.81 & 76.20 & 76.24 & 76.14 \\
\hline Prob $>$ Chi2 & 0.000 & 0.000 & 0.000 & 0.000 & 0.000 & 0.000 & 0.000 & 0.000 & 0.000 & 0.000 \\
\hline
\end{tabular}

${ }^{* * *} p<0.01,{ }^{* *} p<0.05,{ }^{*} p<0.1$, all models are tested using ordered-Probit specifications, Financials dropped from the regression for collinearity issue.

Notes: dependent variable SUSOUAL= sustainability report quality based on 0-4 score; BODFEM= number of female directors on board; PRFEM= proportion of female directors on board; BODINDFEM= number of independent female directors on board; SHANNON= Shannon index of diversity; BLAU= Blau index of diversity; BODSIZE= number of directors on board; BODIND= proportion of independent directors on board; BODMEET= number of board meetings; Reporting incentives (RI)= A single factor reflecting the strength of firm's reporting incentives from various firm's characteristics (i.e. size, leverage, return on assets, book to market ratio, percent of closely held shares, and percent of foreign sales); Reporting behaviour (RB)= the absolute value of accruals scaled by the absolute value of cash flows from operations; Reporting environment (RE)= the natural log of the number of analysts following the firm 


\begin{tabular}{|c|c|c|c|c|c|c|c|c|c|c|}
\hline \multicolumn{6}{|c|}{ Panel B: Small firms $(n=199)$} & \multicolumn{5}{|c|}{ Large Firms $(n=134)$} \\
\hline$D V=S U S Q U A L$ & Model 3.11 & Model 3.12 & Model 3.13 & Model 3.14 & Model 3.15 & Model 3.16 & Model 3.17 & Model 3.18 & Model 3.19 & Model 3.20 \\
\hline BODFEM & $0.299 * *$ & & & & & $0.193^{*}$ & & & & \\
\hline PRFEM & & $2.566^{*}$ & & & & & 0.460 & & & \\
\hline BODINDFEM & & & $0.424^{* * *}$ & & & & & $0.228^{*}$ & & \\
\hline BLAU & & & & $2.617^{* *}$ & & & & & 0.248 & \\
\hline SHANNON & & & & & $1.944^{* *}$ & & & & & 0.028 \\
\hline BODSIZE & 0.067 & $0.112^{* *}$ & 0.064 & $0.106^{* *}$ & $0.102^{* *}$ & $0.214^{* * *}$ & $0.218^{* * *}$ & $0.209 * * *$ & $0.217^{* * *}$ & $0.220 * * *$ \\
\hline BODIND & -0.321 & -0.324 & -0.88 & -0.453 & -0.459 & 0.517 & 0.395 & 0.472 & 0.393 & 0.392 \\
\hline BODMEET & 0.068 & 0.061 & 0.076 & 0.066 & 0.065 & 0.022 & 0.004 & 0.024 & 0.004 & 0.004 \\
\hline RI & $0.648^{* *}$ & $0.653^{* *}$ & $0.566^{* *}$ & $0.661^{* *}$ & $0.666^{* *}$ & $0.104^{*}$ & 0.268 & $0.104^{*}$ & 0.269 & 0.265 \\
\hline $\mathrm{RB}$ & $-0.109^{*}$ & $-0.108^{*}$ & $-0.110^{*}$ & $-0.116^{*}$ & -0.121 & 0.004 & 0.002 & 0.004 & 0.002 & 0.002 \\
\hline RE & 0.173 & 0.184 & 0.151 & 0.199 & 0.209 & 0.027 & 0.005 & 0.041 & 0.007 & 0.012 \\
\hline Oil \& Gas & 0.935 & 0.898 & $0.949^{*}$ & $0.924^{*}$ & 0.911 & $1.616^{* * *}$ & $1.178^{* *}$ & $1.596^{* * *}$ & $0.161^{* *}$ & $1.138^{* *}$ \\
\hline Basic Materials & $2.011^{* * *}$ & $1.964^{* * *}$ & $2.149 * * *$ & $2.122^{* * *}$ & $2.185^{* * *}$ & $3.142^{* * *}$ & $2.122^{* * *}$ & $3.114^{* * *}$ & $2.101^{* * *}$ & $2.074^{* * *}$ \\
\hline Industrials & $0.785^{*}$ & $0.789^{*}$ & $0.751^{*}$ & $0.832^{* *}$ & $0.845^{* *}$ & $1.102^{* * *}$ & $0.781^{* * *}$ & $1.129 * * *$ & $0.768^{* * *}$ & $0.760^{* * *}$ \\
\hline Consumer Goods & $0.932^{* *}$ & $0.932^{* *}$ & $1.005^{\star *}$ & $0.941^{* *}$ & $0.968^{* *}$ & $1.458^{* * *}$ & $1.209^{* * *}$ & $1.430 * * *$ & $1.194^{* * *}$ & $1.189 * * *$ \\
\hline Health Care & -0.113 & 0.008 & -0.372 & -0.031 & 0.004 & $2.001^{* * *}$ & $1.556^{* * *}$ & $1.971^{* * *}$ & $1.532^{* * *}$ & $1.506^{* * *}$ \\
\hline Consumer Services & 0.039 & 0.037 & 0.044 & 0.023 & 0.034 & $0.998^{* * *}$ & $0.704^{* *}$ & $1.015^{* * *}$ & $0.697 * *$ & $0.733^{* *}$ \\
\hline Telecommunication & 0.445 & 0.513 & 0.233 & 0.447 & 0.484 & $1.182^{* * *}$ & $1.431^{* * *}$ & $1.260^{* * *}$ & $1.415^{* * *}$ & $1.407^{* * *}$ \\
\hline Utilities & 0.201 & 0.192 & 0.121 & 0.158 & 0.159 & $7.406^{* * *}$ & $6.903^{* * *}$ & $7.339 * * *$ & $6.897^{* * *}$ & $6.890 * * *$ \\
\hline Technologies & $1.188^{* * *}$ & $1.152^{\star * *}$ & $1.095^{*}$ & $1.101^{*}$ & $1.107^{*}$ & $1.460 * *$ & $0.968^{*}$ & $1.422^{* *}$ & $0.948^{*}$ & 0.922 \\
\hline Pseudo $\mathrm{R}^{2}$ & 0.135 & 0.132 & 0.142 & 0.141 & 0.143 & 0.197 & 0.155 & 0.194 & 0.155 & 0.155 \\
\hline Wald $\chi^{2}$ & 66.49 & 68.72 & 65.15 & 67.07 & 65.73 & 51.95 & 49.68 & 50.99 & 49.85 & 50.17 \\
\hline Prob > Chi2 & 0.000 & 0.000 & 0.000 & 0.000 & 0.000 & 0.000 & 0.000 & 0.000 & 0.000 & 0.000 \\
\hline
\end{tabular}

${ }_{* \star *} p<0.01,{ }^{* *} p<0.05,{ }^{*} p<0.1$, all models are tested using ordered-Probit specifications, Financials dropped from the regression for collinearity issue.

Notes: dependent variable SUSQUAL= sustainability report quality based on 0-4 score; BODFEM= number of female directors on board; PRFEM= proportion of female directors on board; BODINDFEM= number of independent female directors on board; SHANNON= Shannon index of diversity; BLAU= Blau index of diversity; BODSIZE= number of directors on board; BODIND= proportion of independent directors on board; BODMEET= number of board meetings; Reporting incentives (RI)= A single factor reflecting the strength of firm's reporting incentives from various firm's characteristics (i.e. size, leverage, return on assets, book to market ratio, percent of closely held shares, and percent of foreign sales); Reporting behaviour (RB)= the absolute value of accruals scaled by the absolute value of cash flows from operations; Reporting environment (RE)= the natural log of the number of analysts following the firm . 
Table 4 Additional Analysis: Sustainability Reporting Quality and Gender Diversity

\begin{tabular}{|c|c|c|c|c|c|}
\hline \multicolumn{6}{|c|}{ BODSIZE Categorised } \\
\hline$D V=S U S Q U A L$ & Model 4.1 & Model 4.2 & Model 4.3 & Model 4.4 & Model 4.5 \\
\hline BODFEM & $0.172^{\star *}$ & & & & \\
\hline PRFEM & & 0.743 & & & \\
\hline BODINDFEM & & & $0.187^{* *}$ & & \\
\hline BLAU & & & & $0.722^{*}$ & \\
\hline SHANNON & & & & & $0.476^{*}$ \\
\hline \multicolumn{6}{|l|}{ BODSIZE } \\
\hline 0 & base & Base & base & base & base \\
\hline 1 & $3.517^{* * *}$ & $3.637^{* * *}$ & $3.560^{* * *}$ & $3.619^{* * *}$ & $3.616^{* * *}$ \\
\hline 2 & $3.768^{* * *}$ & $3.938^{* * *}$ & $3.825^{* * *}$ & $3.898^{* * *}$ & $3.887^{* * *}$ \\
\hline 3 & $4.241^{* * *}$ & $4.509 * * *$ & $4.284^{* * *}$ & $4.466^{* * *}$ & $4.455^{\star * *}$ \\
\hline BODIND & 0.062 & 0.091 & 0.001 & 0.095 & 0.101 \\
\hline BODMEET & 0.038 & 0.013 & 0.039 & 0.014 & 0.013 \\
\hline RI & $0.599 * * *$ & $0.628^{* * *}$ & $0.586^{* * *}$ & $0.626^{* * *}$ & $0.621^{* * *}$ \\
\hline $\mathrm{RB}$ & -0.007 & -0.003 & -0.007 & -0.003 & -0.002 \\
\hline $\mathrm{RE}$ & $0.235^{* *}$ & $0.254^{* * *}$ & $0.231^{* *}$ & $0.252^{* *}$ & $0.251^{* *}$ \\
\hline Oil \& Gas & $1.028^{* * *}$ & $0.848^{* *}$ & $1.004^{* * *}$ & $0.855^{* *}$ & $0.844^{* *}$ \\
\hline Basic Materials & $2.160 * \star *$ & $1.836^{* * *}$ & $2.155^{* * *}$ & $1.859 * * *$ & $1.855^{\star * *}$ \\
\hline Industrials & $0.771^{* * *}$ & $0.641^{* *}$ & $0.786^{* * *}$ & $0.641^{* *}$ & $0.634^{* * *}$ \\
\hline Consumer Goods & $1.019^{* * *}$ & $0.907^{* * *}$ & $1.016^{* * *}$ & $0.903^{* * *}$ & $0.904^{* * *}$ \\
\hline Health Care & 0.585 & 0.552 & 0.526 & 0.548 & 0.554 \\
\hline Consumer Services & 0.320 & 0.212 & 0.331 & 0.202 & 0.210 \\
\hline Telecommunication & 0.642 & $0.818^{*}$ & 0.518 & $0.886^{* *}$ & $0.888^{*}$ \\
\hline Utilities & 0.687 & 0.568 & 0.660 & 0.552 & $0.551^{*}$ \\
\hline Technologies & $1.020^{* *}$ & $0.824^{* *}$ & $0.990^{* *}$ & $0.821^{* *}$ & $0.819^{* *}$ \\
\hline Pseudo R ${ }^{2}$ & 0.154 & 0.139 & 0.153 & 0.141 & 0.139 \\
\hline Wald $\chi^{2}$ & 106.66 & 98.48 & 101.44 & 98.06 & 97.84 \\
\hline Prob > Chi2 & 0.000 & 0.000 & 0.000 & 0.000 & 0.000 \\
\hline
\end{tabular}

${ }_{* * *} p<0.01,{ }^{* *} p<0.05,{ }^{*} p<0.1$, all models are tested using ordered-Probit specifications, Financials dropped from the regression for collinearity issue.

Notes: dependent variable SUSQUAL= sustainability report quality based on 0-4 score; BODFEM= number of female directors on board; PRFEM= proportion of female directors on board; BODINDFEM= number of independent female directors on board; SHANNON= Shannon index of diversity; BLAU= Blau index of diversity; BODSIZE= number of directors on board [BODSIZE is divided into four-level categories, i.e. 0, 1-7, 8-10, 11-14 and 15-21]; BODIND= proportion of independent directors on board; BODMEET = number of board meetings; Reporting incentives $(\mathrm{RI})=$ A single factor reflecting the strength of firm's reporting incentives from various firm's characteristics (i.e. size, leverage, return on assets, book to market ratio, percent of closely held shares, and percent of foreign sales); Reporting behaviour $(\mathrm{RB})=$ the absolute value of accruals scaled by the absolute value of cash flows from operations; Reporting environment $(\mathrm{RE})=$ the natural log of the number of analysts following the firm. 
Table 5 Additional Analysis: Sustainability Assurance and Gender Diversity

\begin{tabular}{|c|c|c|c|c|c|c|}
\hline$D V=A S S U R A N C E$ & Model 5.1 & Model 5.2 & Model 5.3 & Model 5.4 & Model 5.5 & Model 5.6 \\
\hline BODFEM & & $1.280^{* *}$ & & & & \\
\hline PRFEM & & & 0.465 & & & \\
\hline BODINDFEM & & & & $1.240^{* *}$ & & \\
\hline BLAU & & & & & 0.781 & \\
\hline SHANNON & & & & & & 0.857 \\
\hline BODSIZE & $1.130^{* *}$ & & & & & \\
\hline BODIND & 0.882 & 0.826 & 1.097 & 0.75 & 1.108 & 1.107 \\
\hline BODMEET & 0.992 & 1.054 & 0.996 & 1.043 & 0.999 & 0.999 \\
\hline RI & $3.293^{* * *}$ & $3.569^{* * *}$ & $3.644^{* * *}$ & $3.365^{* * *}$ & $3.649^{* * *}$ & $3.635^{* * *}$ \\
\hline RB & 0.996 & 0.975 & 0.996 & 0.977 & 0.997 & 0.997 \\
\hline RE & $1.492 *$ & $1.947^{*}$ & $1.866^{*}$ & $1.910^{*}$ & $1.856^{*}$ & $1.853^{*}$ \\
\hline Oil \& Gas & $5.792^{* *}$ & $8.082^{* * *}$ & $4.729^{* *}$ & $7.472^{\star * *}$ & $4.850^{* *}$ & $4.858^{* *}$ \\
\hline Basic Materials & $15.111^{* * *}$ & $23.421^{* * *}$ & $11.703^{* * *}$ & $22.401^{* * *}$ & $12.099 * * *$ & $12.086^{* * *}$ \\
\hline Industrials & $2.824^{*}$ & $3.396^{* *}$ & 2.283 & $3.402^{* * *}$ & 2.284 & 2.281 \\
\hline Consumer Goods & 1.963 & $2.264^{\star *}$ & 1.615 & 2.212 & 1.599 & 1.595 \\
\hline Health Care & 1.337 & 1.417 & 1.332 & 1.353 & 1.304 & 1.296 \\
\hline Consumer Services & 1.409 & 1.471 & 1.103 & 1.472 & 1.095 & 1.102 \\
\hline Telecommunication & 2.129 & 0.985 & 1.717 & 1.077 & 2.232 & 2.229 \\
\hline Utilities & 2.508 & 2.809 & 2.068 & 2.673 & 2.047 & 2.046 \\
\hline Technologies & 4.054 & 4.265 & 2.663 & 4.012 & 2.682 & 2.671 \\
\hline _cons & $-5.037^{* * *}$ & $-5.911^{* * *}$ & $-4.513^{* * *}$ & $-5.541^{* * *}$ & $-4.576^{* * *}$ & $-4.571^{* * *}$ \\
\hline Pseudo R² & 0.171 & 0.187 & 0.162 & 0.182 & 0.163 & 0.162 \\
\hline Wald $\chi^{2}$ & 39.75 & 35.66 & 32.81 & 34.46 & 33.34 & 33.17 \\
\hline Prob $>$ Chi 2 & 0.000 & 0.000 & 0.000 & 0.000 & 0.000 & 0.000 \\
\hline
\end{tabular}

${ }_{* * *} p<0.01,{ }^{* *} p<0.05,{ }^{*} p<0.1$, all models are tested using Logistic regression, Financials dropped from the regression for collinearity issue.

Notes: dependent variable ASSURANCE $=1$ if sustainability report is externally assured, 0 otherwise; BODFEM= number of female directors on board; PRFEM= proportion of female directors on board; BODINDFEM= number of independent female directors on board; SHANNON= Shannon index of diversity; BLAU= Blau index of diversity; BODSIZE= number of directors on board; BODIND= proportion of independent directors on board; BODMEET= number of board meetings; Reporting incentives $(\mathrm{RI})=\mathrm{A}$ single factor reflecting the strength of firm's reporting incentives from various firm's characteristics (i.e. size, leverage, return on assets, book to market ratio, percent of closely held shares, and percent of foreign sales); Reporting behaviour (RB)= the absolute value of accruals scaled by the absolute value of cash flows from operations; Reporting environment $(\mathrm{RE})=$ the natural $\log$ of the number of analysts following the firm. 
Table 6 Additional analysis: Sustainability Committee and Gender Diversity

\begin{tabular}{lllllll}
\hline DV=COMMITTEE & Model 6.1 & Model 6.2 & Model 6.3 & Model 6.4 & Model 6.5 & Model 6.6 \\
& & & & & & \\
\hline BODFEM & & $1.381^{* *}$ & & & & \\
PRFEM & & & & & \\
BODINDFEM & & & & & \\
BLAU & & & $1.426^{* *}$ & & \\
SHANNON & & & & $0 . .774^{* *}$ & \\
BODSIZE & $1.130^{* *}$ & & & & $1.239^{* *}$ \\
BODIND & 0.882 & 0.539 & 0.497 & 0.453 & 0.476 & 0.478 \\
BODMEET & 0.992 & 1.055 & 1.044 & 1.071 & 1.044 & 1.043 \\
RI & $3.293^{* * *}$ & $1.828^{*}$ & $1.910^{* *}$ & $1.753^{* *}$ & $1.882^{* *}$ & $1.852^{* *}$ \\
RB & 0.996 & 1.007 & $0.991^{*}$ & 1.006 & $0.990^{*}$ & $0.990^{*}$ \\
RE & $1.492^{*}$ & $1.331^{*}$ & $1.527^{* *}$ & 1.307 & $1.490^{* *}$ & $1.475^{* *}$ \\
Oil \& Gas & $5.792^{* *}$ & 1.328 & 1.333 & 1.29 & 1.377 & 1.35 \\
Basic Materials & $15.111^{* * *}$ & $5.491^{* * *}$ & $4.595^{* * *}$ & $5.135^{* * *}$ & $5.055^{* * *}$ & $5.169^{* * *}$ \\
Industrials & $2.824^{*}$ & $2.719^{* *}$ & $2.639^{* *}$ & $2.585^{* *}$ & $2.716^{* *}$ & $2.698^{* *}$ \\
Consumer Goods & 1.963 & $4.479^{* * *}$ & $4.837^{* * *}$ & $4.394^{* * *}$ & $4.944^{* * *}$ & $5.016^{* * *}$ \\
Health Care & 1.337 & 2.53 & 2.876 & 2.174 & 2.92 & 2.995 \\
Consumer Services & 1.409 & 1.288 & 1.228 & 1.273 & 1.227 & 1.25 \\
Telecommunication & 2.129 & 2.56 & 2.324 & 1.789 & 1.845 & 1.86 \\
Utilities & 2.508 & 2.774 & 2.695 & 2.642 & 2.622 & 2.614 \\
Technologies & 4.054 & 2.668 & 2.355 & 2.753 & 2.44 & 2.479 \\
cons & $-3.470^{* * *}$ & $-2.796^{* * *}$ & $-3.188^{* * *}$ & $-2.691^{* * *}$ & $-3.288^{* * *}$ & $-3.496^{* * *}$ \\
\hline Pseudo R ${ }^{2}$ & 0.117 & 0.115 & 0.122 & 0.112 & 0.125 & 0.126 \\
Wald $X^{2}$ & 36.62 & 39.62 & 42.92 & 38.10 & 44.94 & 45.01 \\
Prob > Chi2 & 0.000 & 0.000 & 0.000 & 0.000 & 0.000 & 0.000 \\
\hline
\end{tabular}

${ }_{* * *} p<0.01,{ }^{* *} p<0.05,{ }^{*} p<0.1$, all models are tested using Logistic regression, Financials dropped from the regression for collinearity issue.

Notes: dependent variable COMMITTEE $=1$ if sustainability committee exists, 0 otherwise; BODFEM= number of female directors on board; $\mathrm{PRFEM}=$ proportion of female directors on board; BODINDFEM= number of independent female directors on board; SHANNON= Shannon index of diversity; BLAU= Blau index of diversity; BODSIZE= number of directors on board; $\mathrm{BODIND}=$ proportion of independent directors on board; $\mathrm{BODMEET}=$ number of board meetings; Reporting incentives $(\mathrm{RI})=\mathrm{A}$ single factor reflecting the strength of firm's reporting incentives from various firm's characteristics (i.e. size, leverage, return on assets, book to market ratio, percent of closely held shares, and percent of foreign sales); Reporting behaviour (RB)= the absolute value of accruals scaled by the absolute value of cash flows from operations; Reporting environment $(\mathrm{RE})=$ the natural log of the number of analysts following the firm. 